not adequate for many pasture studies, and improved relationships must still be looked for.

Briefly then, it appears that we now require techniques for measuring and comparing pasture outputs over relatively short periods, rather than over the whole season, as has generally been done. The measurement of animal production over short periods is liable to considerable errors, and as a measure of output is very sensitive to skill in pasture management. For a more complete measure of pasture output information on herbage consumption is also required. Two main methods of estimating herbage intake are at present being studied, involving herbage cutting or faecal measurements, and improvements in the precision of these techniques are urgently needed in further studies of pasture evaluation.

\title{
REFERENCES
}

Cox, C. P., Foot, A. S., Hosking, Z. D., Line C. \& Rowland, S. J. (1956). F. Brit. Grassl. Soc. II, 107. Eyles, D. E., Williams, T. E. \& Green, J. O. (1956). Proc. Brit. Soc. Anim. Prod. p. 91.

Holmes, W., Waite, R., Fergusson, D. L. \& MacLusky, D. S. (1952). F. agric. Sci. 42, 304.

Raymond, W. F. (1956). Agric. Rev. 2, 43.

Raymond, W. F. \& Minson, D. J. (1955). F. Brit. Grassl. Soc. 10, 282.

van der Kley, F. K. (1956). Neth. F. agric. Sci. 4, 197.

Woodman, H. E., Blunt, D. L. \& Stewart, J. (1927). F. agric. Sci. 17, 209.

\section{Some effects of spring grass on rumen digestion and the metabolism of the dairy cow}

\author{
By M. J. HeaD and J. A. F. Rook, National Institute for Research in Dairying, \\ Shinfield, near Reading
}

During the last two decades, there has been a marked increase in the productivity of our grasslands. It has been achieved, in part, by the application of heavier dressings of fertilizer, especially nitrogenous fertilizer, which tends to produce an early spring growth of succulent herbage of high crude-protein content. This type of herbage, often containing $25-35 \%$ crude protein on a dry-matter basis, provides the grazing cow with an unbalanced ration when judged by accepted feeding standards, an excess of protein $(\mathrm{N} \times 6.25)$ being consumed in relation to both the cow's protein requirements and to the starch equivalent consumed.

In the ruminant, the preliminary fermentation within the rumen has a profound effect on the subsequent digestion and metabolism of the feed constituents. With nitrogenous substances, the end-product of the katabolic microbial processes is ammonia which is, however, concurrently elaborated by other micro-organisms into the constituents of their bodies. The study of the fermentation in vivo is complicated by this resynthesis of breakdown products and by the continuous absorption of substances from the rumen by the blood and the passage of digesta to the omasum. 


\section{Studies on nitrogen digestion and metabolism}

Rumen fermentation on winter feed and grass. We have studied the detailed pattern of the rumen fermentation during winter feeding and the early grazing period in terms of $\mathrm{pH}, \mathrm{Eh}$, buffering capacity, total and individual volatile acids and fractionation of the nitrogenous constituents. We are concerned in this paper only with the nitrogen fraction, and the most characteristic feature of the rumenal fermentation of spring grass has been a higher ammonia content of the rumen liquor and its higher proportion of the total nitrogen than is common on winter rations. The ammonia content of the rumen liquor after a typical meal of hay and dairy concentrates is shown in Fig. I. In stall-fed dairy cows each meal is eaten in $\mathrm{I}-2 \mathrm{~h}$ and there is little food intake for the following 8-12 h. As a result the

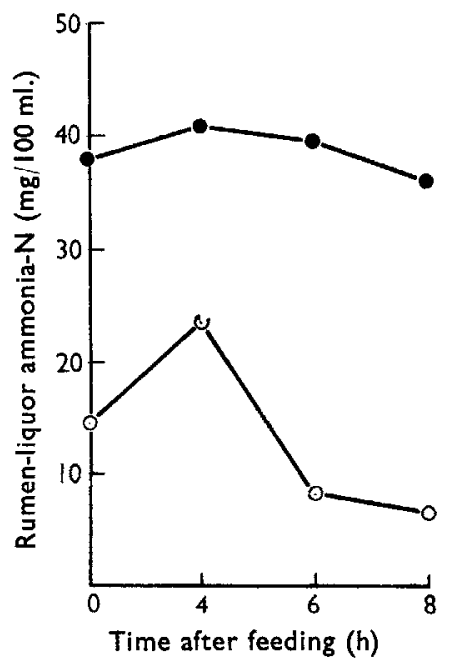

Fig. 1. Mean ammonia nitrogen in rumen liquor of four dry cows on hay and concentrates and grazing.

$\bullet-\bullet$, grazing; $0-0$, hay and concentrates.

fermentation rate is cyclic with a peak some $2-4 \mathrm{~h}$ after feeding, the time depending largely on the nature of the protein (cf. Chalmers \& Synge, 1954) and the proportion of starch in the meal.

At grazing, the consumption of food by dairy cattle is more or less continuous, although there are periods of more intensive grazing interspersed with rest periods. The meals are more frequent and smaller and, as a result, the rate of fermentation is more stable because the fermentation of one meal overlaps that of another. Ammonia production during a typical $8 \mathrm{~h}$ grazing period is shown in Fig. $\mathrm{I}$.

The results in Fig. I show that in the experiments cited the average ammonianitrogen content of rumen liquor was, over equivalent $8 \mathrm{~h}$ periods, $13 \cdot 2 \mathrm{mg} / 100 \mathrm{ml}$. on a ration of hay and concentrates and $4 \mathrm{I} \cdot 3 \mathrm{mg} / \mathrm{r} 00 \mathrm{ml}$. on grazing. This threefold increase in the concentration of ammonia in rumen liquor at the beginning of grazing is considered significant in view of the several pathways, mentioned earlier, for the constant removal of ammonia. 
The higher concentration of ammonia in the rumen liquor during grazing may result simply from the breakdown of the increased amount of nitrogenous substances entering the rumen during the early grazing period. Alternatively, the anabolic processes of some micro-organisms may be restricted by accompanying changes in rumen liquor such as in oxidation-reduction potential.

Table I. Effect of the addition of starch to the rumen on the concentration of ammonia in the rumen liquor

\begin{tabular}{|c|c|c|c|c|}
\hline \multirow[b]{3}{*}{$\begin{array}{l}\text { Time after addition } \\
\text { of starch } \\
\text { (h) }\end{array}$} & \multicolumn{4}{|c|}{ Ammonia in rumen liquor* $(\mathrm{mg} / 100 \mathrm{ml}$.) } \\
\hline & \multicolumn{2}{|c|}{ Cow no. $\mathbf{I}$} & \multirow{2}{*}{\multicolumn{2}{|c|}{$\begin{array}{cc} & \text { Cow no. } 2 \\
& \text { Grazing alone on } \\
& \text { same day as } \\
\text { Grazing } & \text { starch given } \\
\text { alone } & \text { to cow no. I }\end{array}$}} \\
\hline & $\begin{array}{l}\text { Grazing } \\
\text { alone }\end{array}$ & $\begin{array}{l}\text { Grazing } \\
\text { and starch }\end{array}$ & & \\
\hline 0 & $31 \cdot 0$ & $33 \cdot 5$ & $24 \cdot 0$ & $26 \cdot 5$ \\
\hline 2 & $35 \cdot 8$ & $17 \cdot 5$ & $26 \cdot 0$ & $26 \cdot 5$ \\
\hline 4 & 33.0 & $16 \cdot 0$ & $26 \cdot 5$ & $24 \cdot 0$ \\
\hline 6 & $35 \cdot 0$ & 10.5 & $3 I \cdot 5$ & $34 \cdot 0$ \\
\hline 8 & $32 \cdot 3$ & $\begin{array}{l}17 \cdot 0 \\
\text { values for }\end{array}$ & $28 \cdot 0$ & $39 \cdot 3$ \\
\hline
\end{tabular}

Rumen-ammonia concentration in the presence of starch. A reduction of the ammonia concentration in the rumen liquor under grazing conditions can be readily attained by the addition of starch to the rumen via a permanent fistula (Table I). Macdonald (1952) had earlier shown that the level of ammonia in the rumen of grazing sheep could also be depressed by the feeding of starch. The mode of action of starch in controlling the concentration of rumen ammonia may be that it either provides an energy source for micro-organisms which utilize the ammonia as their nitrogen source, or controls rumen conditions so that excessive bacterial deamination does not take place. Work is continuing to elucidate this problem.

Absorption of ammonia from the rumen. Absorption of ammonia from the rumen has been demonstrated by Macdonald (1948), and Dr D. Lewis \& Dr K. Hill of the Institute of Animal Physiology, Babraham (private communication) have found that the concentration of ammonia in portal blood is proportional to that in the rumen liquor. The presence of ammonia in peripheral blood in concentrations above $4 \mathrm{mg} / 100 \mathrm{ml}$. is known to be toxic to animals (Dinning, Briggs, Gallup, Orr \& Butler, 1948), but the liver normally detoxifies to urea the ammonia carried to it by the portal blood supply. The values in Fig. 2 indicate that when the rumenammonia level rises at the beginning of the grazing of herbage of high crudeprotein content, the serum-urea level also rises and increased quantities of ammonia appear in peripheral blood. The highest concentration of ammonia so far found in peripheral blood is $0.385 \mathrm{mg} / 100 \mathrm{ml}$, , which is well below the toxic level. It is considered that the rise in serum urea and blood ammonia under these conditions reflects the rise in the rumen-ammonia level, and does not result merely from an increased nitrogen intake, since the levels fall when starch is added to the rumen via a fistula to control the rumen-ammonia concentration. 

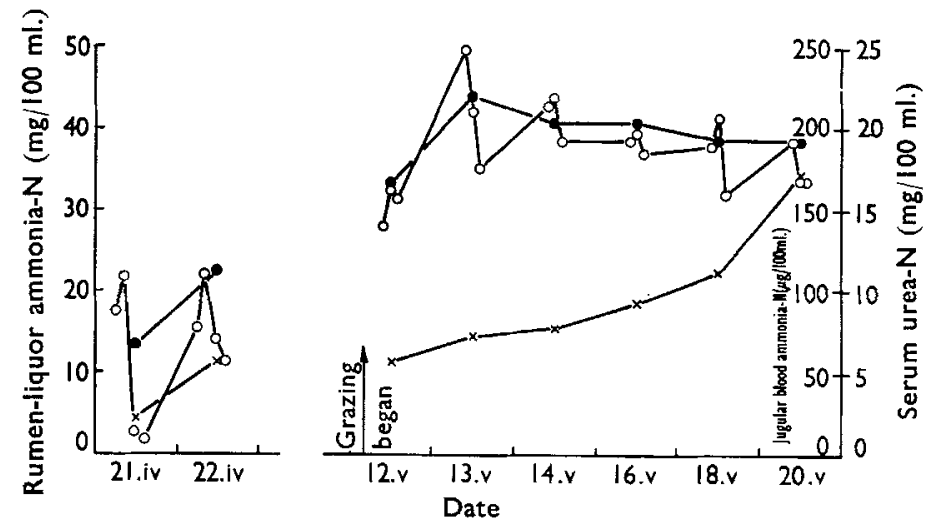

Fig. 2. Mean ammonia nitrogen in rumen liquor and in jugular blood and urea in blood serum of two milking cows on winter rations and grazing. $0-0$, rumen liquor; $x \longrightarrow x$, jugular blood; $\bullet-\bullet$, serum.

Nitrogen retention. The nitrogen absorbed from the rumen as ammonia is of little nutritive value to the animal. Macdonald (1948) found with sheep that saliva returned to the rumen as urea less than one-eighth of the nitrogen absorbed as ammonia. Table 2 shows the amount of nitrogen appearing in the urine when grass of high crude-protein content is given to dairy cows and the decrease in the urinary nitrogen excretion obtained when starch is added to a grass ration. Head (1953) has earlier shown the effectiveness of starch in controlling urinary wastage of nitrogen from a variety of proteins.

The association of high rumen-ammonia concentration with hypomagnesaemia

The products of the rumenal digestion of the nitrogenous compounds of spring grass are thought to be concerned also with the production of hypomagnesaemia

Table 2. Urinary excretion of nitrogen (lb./4 days) of cows receiving frozen grass with and without starch

\begin{tabular}{|c|c|c|}
\hline \multirow[b]{2}{*}{ Cow } & \multicolumn{2}{|c|}{ Nitrogen excretion on diet of: } \\
\hline & Frozen grass & $\begin{array}{l}\text { Frozen grass with } \\
6 \mathrm{lb} \text {. starch/day }\end{array}$ \\
\hline$\underset{\text { (lactating) }}{\mathrm{A}^{*}}$ & $1 \cdot 5 I$ & $\mathrm{I} \cdot 30$ \\
\hline $\begin{array}{c}\mathrm{B}^{*} \\
\text { (dry) }\end{array}$ & $\mathbf{r} \cdot 36$ & $\mathbf{1} \cdot \mathbf{0 3}$ \\
\hline$\underset{\text { (dry) }}{\mathrm{C} \dagger}$ & $\mathbf{I}-2 \mathbf{I}$ & $x \cdot 14$ \\
\hline * r $20 \mathrm{lb} . \mathrm{fr}$ & +80 & frozen grass/day. \\
\hline
\end{tabular}


in dairy cows during the spring grazing period (Head \& Rook, 1955). The hypomagnesaemia is due to a low availability to the cow of the magnesium of spring herbage, coupled in certain instances with a low intake of magnesium compared with that during winter feeding (Balch, Head, Line, Rook \& Rowland, I956). In any particular instance, the incidence of hypomagnesaemia is dependent on the severity of these two factors, together with the cow's inherent capacity to absorb magnesium, and its individual requirements. We have suggested earlier (Head \& Rook, 1955) that the low availability of the magnesium of certain types of spring herbage may be associated with an abnormal digestion and metabolism of the nitrogenous constituents of the herbage.

Bartlett, Brown, Foot, Rowland, Allcroft \& Parr ( 1954) have found that the application of heavy dressings of sulphate of ammonia to a cocksfoot sward increased the incidence of hypomagnesaemia in cattle grazing the sward. We have confirmed the observation on certain other swards and have shown that, when there is a response to the nitrogen fertilizer, hypomagnesaemia is most severe in those groups having the highest serum non-protein nitrogen and blood ammonia levels (Table 3 ).

Table 3. Relationship between the levels of serum magnesium, serum non-protein nitrogen and blood ammonia in cows grazing a sward fertilized in different ways

\begin{tabular}{|c|c|c|c|c|}
\hline Sward no. & $\begin{array}{l}\text { Crude protein } \\
\text { in herbage } \\
\text { dry matter } \\
(\%)\end{array}$ & $\begin{array}{l}\text { Mean serum } \\
\text { non-protein } \\
\text { nitrogen } \\
(\mathrm{mg} / \mathrm{I} 00 \mathrm{ml} .)\end{array}$ & $\begin{array}{l}\text { Mean blood } \\
\text { ammonia } \\
\text { nitrogen } \\
(\mu \mathrm{g} / \text { roo ml. })\end{array}$ & $\begin{array}{c}\text { Mean minimum } \\
\text { serum } \\
\text { magnesium } \\
(\mathrm{mg} / \mathrm{ro0} \mathrm{ml} .)\end{array}$ \\
\hline $\mathbf{I}^{*}$ & $23 \cdot 8$ & $40 \cdot 2$ & 40.8 & 1.00 \\
\hline $2^{*}$ & $18 \cdot 8$ & $34 \cdot 3$ & $3 x \cdot 4$ & I. 55 \\
\hline $3 \dagger$ & $14 \cdot 9$ & $29 \cdot 2$ & $20 \cdot 2$ & $I \cdot 90$ \\
\hline
\end{tabular}

We have inferred from this result and the results already presented that the high rumenal ammonia concentration was affecting the utilization of the herbage magnesium. Confirmation of this hypothesis has been obtained by artificially raising the level of ammonia in the rumen of a cow eating hay and concentrates, thus lowering the availability of the ingested magnesium from $4 \mathrm{I} \%$ to $24 \%$ (Head \& Rook, 1955). Furthermore, an increase in serum magnesium levels in cattle that had developed hypomagnesaemia during the feeding of frozen grass, was effected by the addition to the rumen through a fistula of raw maize starch, which caused a drastic reduction in rumen-ammonia levels. In some experiments with sheep, we have also demonstrated a radical fall in the concentration of ultrafiltrable magnesium in the absorptive region of the small intestine of from 5 to $15 \mathrm{mg} / 100 \mathrm{ml}$. digesta on a hay and concentrate ration to nought in certain instances on changing the ration to cut grass rich in crude protein.

It is clear that there is some association between the low availability of the magnesium from spring herbage and the presence of continuously high levels of ammonia in the rumen, but the mechanism is unknown. It is of course possible that the presence of much ammonia in the rumen merely reflects the concentration of another 
constituent more directly responsible. For instance, there is evidence to suggest that a low level of amino-acids in the digesta of the small intestine may depress the absorption of magnesium from that organ (McCance \& Widdowson, 1944), and this level could well be related to the type of fermentation proceeding in the rumen.

This brief account of our investigation of the pattern of rumen fermentation and the metabolism of the cow has indicated the special features and problems connected with the feeding of spring grass, but clearly much further study along these lines is required.

We should like to record our appreciation of the constant advice and criticism of Dr S. J. Rowland throughout the course of our work. Many of the experiments reported have been done in association with $\mathrm{Dr} \mathrm{C}$. C. Balch and we are grateful to him, and to $\operatorname{Dr} A$. T. Cowie for establishing the rumen and intestinal fistulas in the cows and sheep.

\section{REFERENCES}

Balch, C. C., Head, M. J., Line, C., Rook, J. A. F. \& Rowland, S. J. (1956). Proc. Nutr. Soc. 15, X. Bartlett, S., Brown, B. B., Foot, A. S., Rowland, S. J., Allcroft, R. \& Parr, W. H. (1954). Brit. vet. $\mathcal{Y}$. rro, 3 .

Chalmers, M. I. \& Synge, R. L. M. (1954). 7. agric. Sci. 44, 263.

Dinning, J. S., Briggs, H. M., Gallup, W. D., Orr, H. W. \& Butler, R. (1948). Amer. F. Physiol. $153,4 I$.

Head, M. J. (1953). F. agric. Sci. 43, $28 \mathrm{I}$.

Head, M. J. \& Rook, J. A. F. (1955). Nature, Lond., 176, 262.

McCance, R. A. \& Widdowson, E. M. (1944). Annu. Rev. Biochem. r3, 315.

McDonald, I. W. (1948). Biochem. F. 42, 584 .

McDonald, I. W. (r952). Biochem. F. 5I, 86.

The influence of pasture on the vitamin $A$ and carotene in the milk of cows

By W. A. McGillivray, Massey Agricultural College, Palmerston North, New Zealand, and S. Y. Thомтsоn, National Institute for Research in Dairying, Shinfield, near Reading

Vitamin A and carotene in milk and milk products make a valuable contribution to human nutrition, and this contribution depends on the feeding of the cow.

The daily allowance of vitamin A for an adult man recommended by the (U.S.A.) National Research Council: Food and Nutrition Board (1953) and the British Medical Association: Committee on Nutrition (1950) is 5000 i.u. from sources containing both carotene and vitamin A. A reasonable estimate of the contribution of milk and milk products can be calculated on the assumption, valid for the fatsoluble vitamins at least, that they quantitatively find their way into the diet of the population. The total sale of milk for all purposes in this country is virtually $2 \times 10^{9} \mathrm{gal} . / \mathrm{year}$, which distributed to a population of 53 million works out at $4{ }^{\circ}$ gal./head annually, or $500 \mathrm{~g} /$ day. The Milk Marketing Board statistics (Provan, r955) show that in England and Wales milk contains on the average $3.6 \%$ fat, and 